\title{
Rational design and synthesis of quinazoline derivatives
}

\author{
Fatimah AlKharaz (1D, Zead Abudayeh¹ (D), Qais Abualassal' (1), Loay Hassouneh² (1) \\ 'Isra University, Faculty of Pharmacy, Department of Applied Pharmaceutical Sciences, Amman, Jordan \\ ${ }^{2}$ Isra University, Faculty of Pharmacy, Department of Basic Pharmaceutical Sciences, Amman, Jordan
}

ORCID IDs of the authors: F.A. 0000-0001-9198-0603; Z.A. 0000-0003-4879-5634; Q.A. 0000-0002-6784-3147;

L.H. 0000-0002-8278-7278

Cite this article as: AlKharaz, F., Abudayeh, Z., Abualassal, Q., \& Hassouneh, L. (2021). Rational design and synthesis of quinazoline derivatives. Istanbul Journal of Pharmacy, 51(1), 50-58.

\begin{abstract}
Background and Aims: Alzheimer's disease is a neurodegenerative disorder in which the death of brain cells causes memory loss and cognitive decline. It is one of the leading causes of mortality worldwide. Several different hallmarks of the disease have been reported such as low levels of acetylcholine, deposits of $\beta$-amyloid around neurons, hyperphosphorylated tau protein, oxidative stress, etc. Pharmacotherapy for this disease currently depends on using acetylcholinesterase inhibitors and $\mathrm{N}$-methyl-D-aspartate receptor antagonists. They provide only symptomatic relief and mostly targets cognitive revival. Quinazoline derivatives were recently reported as being a valuable template in the treatment of many neurodegenerative disorders. Quinazoline based compounds were declared as being potential anti AD agents. This research focuses on the synthesis of novel quinazoline derivatives $\mathbf{3}$ and $\mathbf{4}$.

Methods: Novel quinazoline derivatives $\mathbf{3}$ and $\mathbf{4}$ were synthesized starting from 2-(methylamino) benzamide by consecutive steps. The structures of these compounds have been characterized using different analytical and spectral methods: TLC, GC-MS, ${ }^{1} \mathrm{H}-\mathrm{NMR}$ and ${ }^{13} \mathrm{C}-\mathrm{NMR}$.

Results: This study revealed the synthesis of the novel compounds $\mathbf{3}$ and $\mathbf{4}$ with excellent yields equalling $97 \%$ and $73.1 \%$ respectively.

Conclusion: Novel quinazoline derivatives compounds $\mathbf{3}$ and $\mathbf{4}$ were obtained. These compounds might be promising lead compounds for potential poly-functional anti-Alzheimer's agents in future work.

Keywords: Quinazoline derivatives, Synthesis, Reaction conditions
\end{abstract}

\section{INTRODUCTION}

Alzheimer's disease (AD) is an age-related, gradual, and irreversible neurodegenerative disorder characterized by cognitive and memory failure, and it is the most common cause of dementia in elderly persons. Between 1997 and 2050, the older population, defined as adults 65 years of age and older, will increase from 63 to 137 million in the Americas, from 113 to 170 million in Europe, from 18 to 38 million in Africa and from 172 to 435 million in Asia. The estimated spread of this disease in 2015 was 44 million people all over the world and it is estimated that this number will double by 2050 and there are many studied defined risk factors for AD, age is the greatest leading factor for the AD (Apostolova, 2016; Hung \& Fu, 2017). The likelihood of developing AD increases greatly with age. Gender can also change the prevalence of AD. Nearly two-thirds of all patients diagnosed with AD are women. General health status plays a role in AD: high blood cholesterol levels have been suggested as risk factors for AD and there is an association between high blood pressure and AD. However, this association is complex and differs with age. It has been shown that high blood pressure in middle age is associated with an increased risk of AD; while other studies found no association between hypertension in the older persons and dementia (Lazo-Porras et al., 2017). Several studies linking obesity to increased cognitive decline and AD 
risk (Naderali, Ratcliffe, \& Dale, 2009). Studies in both human and animal models suggest that particular dietary constituents may be important in modulating AD risk. For example, a high fatty acid diet is associated with obesity and thus with a higher risk of AD. It was recently reported that a high-fat diet causes damage similar to that noticed in Alzheimer's pathology. Type 2 diabetes mellitus is considered an independent risk factor for AD (Naderali et al., 2009; Bekris, Yu, Bird, \& Tsuang, 2010; Panpalli, Karaman, Guntekin, \& Ergun, 2016; Mendiola-Precoma, Berumen, Padilla, \& Garcia-Alcocer, 2016; Lazo-Porras et al 2017; Tariq \& Barber 2017; Kivimäki \& Singh-Manoux, 2018; Benny \& Thomas, 2019). Family history of sporadic AD is a well-established risk factor. Individuals who have a first-degree relative diagnosed with $A D$ are more likely to develop the disease than those who do not (Bekris et al., 2010). Genetic makeup is not the only risk; shared environmental and lifestyle factors likely also play a role (Apostolova, 2016).

Cognition is the combination of two vital components, i.e., learning and memory. In many diseases like AD and dementia, the cognition is changed based on the severity of the disease. The concept of cognition and the function of central cholinergic transmission in the acquisition of cognitive roles has been recognized since the early sixties. Several neurotransmitters have role in the acquisition of learning and memory, but, the part of the cholinergic system is the most important role for neurological researchers (Benny \& Thomas, 2019; Szeto, Simon, \& Lewis, 2016).

The Cholinergic hypothesis was suggested thirty five years ago (Darras, Wehle, Huang, Sotriffer, \& Decker, 2014). It revolutionized the area of $A D$ research by transporting it from the field of descriptive neuropathology to the recent concept of synaptic neurotransmission. It is based on three fundaments: the detection of depleted presynaptic cholinergic markers in the cerebral cortex; the finding that the neurons from the nucleus basalis of Meynert (NBM) in the basal forebrain, which are the origin of cortical cholinergic transmitters that undergo intense neurodegeneration in $A D$; and the confirmation that cholinergic antagonists decline memory whereas agonists have the counter effect. The hypothesis received compulsory validation when cholinesterase inhibitor drugs such as tacrine (Cognex, later disused because of harmful effects), donepezil (Aricept), galantamine (Reminyl), and rivastigmine (Exelon) were shown to produce significant symptomatic improvement in patients with AD. Although other pertinent pathophysiological mechanisms have got more research awareness in last years, treatments that improve cholinergic role remain definitive in the management of patients with $A D$. These compounds are usually prescribed at the early stages of $A D$ when cognitive symptoms are light to moderate (Douchamps \& Mathis, 2017; Hampel et al., 2018).

Benefits noticed as cognitive performances increase or at least stabilize, and there is an overall improvement in the activities of daily life. These drugs are the only ones approved so far as AD directed treatments, with the single exception of NMDA antagonist memantine (Olivares, et al., 2012; Douchamps \& Mathis, 2017; Hampel et al., 2018).

Quinazoline is one of the benzodiazine family with its heteroatomic nitrogen located at 1- and 3-positions (Ajani, Ad- erohunmu, Umeokoro, \& Olomieja, 2016). These backbone structures were declared as potential anti AD agents and novel quinazoline-urea analogues were recently reported as being valuable templates in the treatment of many neurodegenerative disorders (Kamel, Zaghary, Al-Wabli, \& Anwar, 2016; Park et al., 2017). Moderate or strong inhibitory effects of 3,4-dihydroquinazoline derivatives towards acetylcholinesterase enzyme (AChE) were also reported. Furthermore some new 2-(2-indolyl-)-4(3H)-quinazoline derivatives were designed, synthesized and the biological evaluation of these new derivatives including anti AChE activity, kinetic analysis and molecular modeling of the AChE inhibition were investigated ( $\mathrm{Li}$ et al., 2013). Many studies have highlighted 2,4-disubstituted quinazoline as cholinesterase inhibitors (Mohamed, Manna, \& Rao, 2017; Mohamed \& Rao, 2017). Based on the previously mentioned studies, we decided to synthesize new quinazoline derivatives as potential acetylcholinesterase enzyme inhibitor.

\section{MATERIALS AND METHODS}

\section{Chemicals, instrumentation and analytical methods}

$\mathrm{N}$-Methylisatoic anhydride, lithium aluminium hydride $\left(\mathrm{LiAlH}_{4}\right)$, cycloheptanone, tetrahydrofuran (THF) anhydrous, trimethylsilyl chloride (TMSCI), all were purchased from Sigma Aldrich. Ammonia solution 32\% from (ALPHA chemika company), ethyl acetate and $\mathrm{n}$-hexane from (Tedia ${ }^{\oplus} \mathrm{HPLC} /$ spectro), petroleum ether purchased from (Pharmaco), sodium hydroxide $(\mathrm{NaOH})$ purchased from (Extra pure Sand C chemicals supply co chemicals laboratory chemicals), water $\left(\mathrm{H}_{2} \mathrm{O}\right) \mathrm{HPLC}$ grade and methanol GC grade, were in compliance to the specification of USP, BP, EP grades purchased from (Lab chem), toluene-4-sulfonic acid monohydrate, hydrochloric acid ( $\mathrm{HCl}$ ) 37\%, sodium sulphate $\left(\mathrm{Na}_{2} \mathrm{SO}_{4}\right)$ anhydrous and dichloromethane (DCM) all were purchased from (AZ Chem for chemicals), triethylamine (TEA) purchased from (Riedel-deHaen), acetonitrile purchased from (chem. lab. HPLC grade). All reagents and solvents were purchased from different commercial suppliers and utilized without any further modifications.

Thin-layer chromatography (TLC) plates (silica gel 60 coated with fluorescent indicator F254) were purchased from SigmaAldrich, which were visualized by exposing to iodine vapours and UV light. Mobile phase used was ethyl acetate: petroleum ether 1:1, v/v, for monitoring 2 synthesis and hexane: ethyl acetate 1:1, v/v used for $\mathbf{3}$ and $\mathbf{4}$ synthesis. Column dimension utilized $(60 \mathrm{~cm} \times 1 \mathrm{~cm}$, or larger column based on the weight and the purity of sample), wet method was used for column packing with silica gel $60 \AA$ (average particle size 63-200 $\mu \mathrm{m}$, $60 \mathrm{~g}$ silica/1 $\mathrm{g}$ of product) loaded onto the top of the silica bed and the isocratic mobile phases used were ethyl acetate: petroleum ether (2:8) for purification of compound $\mathbf{2}$, and DCM: ethyl acetate : TEA (160:40:4) v/v for the purification of compound 3. Compounds were detected by a UV-light detector. Fractions possessing the same purity were collected together, concentrated using a rotary evaporator.

${ }^{1} \mathrm{H}$ NMR $(500.13 \mathrm{MHz})$ and ${ }^{13} \mathrm{C}$ NMR spectra (125.75 MHz) were recorded on a Bruker Avance NMR spectrometer (Bruker, Karlsruhe, Germany). Chemical shifts were recorded in ppm ( $\delta$ ) and were referenced to internal tetramethylsilane (TMS) and 
coupling constants ( $J$ values) are expressed in Hz. To monitor the progress of reactions gas chromatography-mass spectrometer (GC-2010 plus Shimadzu) with flame ionization detection (FID) was used. GCMS real-time analysis software from Craig S Young. Sr. Technical Support. Shimadzu Scientific Instruments was used for data acquisition from the FID. The Perkin-Elmer column (25 m x 0.32 mm, $1.0 \mu \mathrm{m}$ film thickness) was utilized. Helium was used as the carrier gas (purity 99.995\%) with a splitless injection (100:1). The splitless injector temperature was $250^{\circ} \mathrm{C}$ and oven column temperature was $150^{\circ} \mathrm{C}$. Samples were dissolved in methanol (GC grade in compliance to the specification of USP, BP, EP grade. Lab chem).

\section{Synthesis of target compounds 2-4}

Synthesis of compound $\mathbf{2}$

2-(Methylamino)benzamide $\left(\mathrm{C}_{8} \mathrm{H}_{10} \mathrm{~N}_{2} \mathrm{O}\right)$ (2) was synthesized as previously reported

(Zhao, Wang, \& Li, 2014) with slight modifications: N-Methylisatoic anhydride $(5 \mathrm{~g}$ ) was stirred with $125 \mathrm{ml}$ ammonia aqueous solution in a 250 round bottom flask at $30{ }^{\circ} \mathrm{C}$ for 60 minutes. The mixture was cooled to room temperature and the solvent was removed in a vacuum. Then, the mixture was purified using column chromatography by elution solvent ethyl acetate: petroleum ether (2:8).

Synthesis of compound $\mathbf{3}$

The synthesis of compound $\mathbf{3}$ was achieved as previously reported method (Abualassal, Abudayeh, \& Husien- Al-Ali, 2019) with some modifications: Toluene-4-sulfonic acid monohydrate $302 \mathrm{mg}$ (0.13 eq) was stirred with $5 \mathrm{ml}$ cycloheptanone followed by the addition $2.036 \mathrm{~g}$ (1 eq) of compound $\mathbf{2}$ previously prepared in methanol under reflux for $3 \mathrm{~h}$. The reaction mixture was cooled to room temperature and thin stirred for $24 \mathrm{~h}$. TLC and GC-MS revealed complete consumption of compound $\mathbf{2}$ with presence of our target product 3. The solvent in reaction mixture was removed under vacuum. The purification achieved using column chromatography with 160:40:4 DCM: ethyl acetate: TEA and recrystallized from methanol.
Synthesis of compound $\mathbf{4}$

Compound $\mathbf{4}$ was synthesized starting from the activation of amide group with TMSCI followed by reduction with Li$\mathrm{AlH}_{4}$. This method permitted the target compound $\mathbf{4}$ to give an excellent yield (Scheme 1). The target compounds 2-4 were characterized by ${ }^{1} \mathrm{HNMR},{ }^{13} \mathrm{C}$ NMR and GCMS methods.

\section{Synthesis of 2-methylaminobenzamide (2).}

\%Yield (85.71\%), color: white crystals, Rf : 0.5 (EtOAc/Petroleum ether $=2: 8)$, MS $m / z=150$. (Figure1).

${ }^{1} \mathrm{H}-\mathrm{NMR}(500 \mathrm{MHz}, \mathrm{DMSO}): \mathbb{Q}=2.78\left(\mathrm{~d}, 3 \mathrm{H}, J=4.85 \mathrm{~Hz}, \mathrm{CH}_{3}\right) 3.32$ $(\mathrm{s}, 1 \mathrm{H}, \mathrm{NH}), 6.52(\mathrm{t}, 1 \mathrm{H}, J=7.45 \mathrm{~Hz}, \mathrm{ArH}), 6.62(\mathrm{~d}, 1 \mathrm{H}, J=8.3 \mathrm{~Hz}$, $\mathrm{ArH}), 7.28\left(\mathrm{td}, 1 \mathrm{H}, J_{1}=7.6 \mathrm{~Hz}, J_{2}=0.2 \mathrm{~Hz}, \mathrm{ArH}\right), 7.59(\mathrm{~d}, 1 \mathrm{H}, J=$ $7.8 \mathrm{~Hz}, \mathrm{ArH}), 7.11,7.88\left(2 \mathrm{br} \mathrm{s}, \mathrm{NH}_{2}\right.$ ). (Figure 2).

\section{1'-Methyl-1 H'-spiro[cycloheptane-1,2'-quinazolin]- 4'(3'H)-one (3).}

\%Yield: (98\%), color: brown crystals, Rf : 0.7 (Hexane/EtOAc= $1: 1)$, MS $m / z=244$. (Figure 3).

${ }^{1} \mathrm{H}-\mathrm{NMR}\left(500 \mathrm{MHz} \mathrm{CDCl}_{3}\right): \delta=1.56-1.99\left(\mathrm{~m}, 12 \mathrm{H}, 2^{\prime}-\mathrm{H} 2-7^{\prime}-\mathrm{H} 2\right)$ $2.81(\mathrm{~s}, 3 \mathrm{H}, \mathrm{CH} 3), 6.63(\mathrm{~d}, 1 \mathrm{H}, J=8.2 \mathrm{~Hz}, \mathrm{ArH}), 6.78\left(\mathrm{dd}, 1 \mathrm{H}, J_{1}=\right.$ $\left.7.35 \mathrm{~Hz}, J_{2}=0.1 \mathrm{~Hz}, \mathrm{ArH}\right), 7.34\left(\mathrm{dd}, 1 \mathrm{H}, J_{1}=7.8 \mathrm{~Hz}, J_{2}=0.35 \mathrm{~Hz}\right.$, $\operatorname{ArH}), 7.58(\mathrm{~s}, 1 \mathrm{H}, \mathrm{NH}), 7.89(\mathrm{~d}, 1 \mathrm{H}, J=7.45 \mathrm{~Hz}, 1 \mathrm{H}, \mathrm{ArH})$. (Figure 4).

${ }^{13}$ C-NMR (125 Hz, CDCl $): \delta=22.97,30.46$ (cyclohept.), 31.29 $\left(\mathrm{NCH}_{3}\right), 37.98$ (cyclohept.),

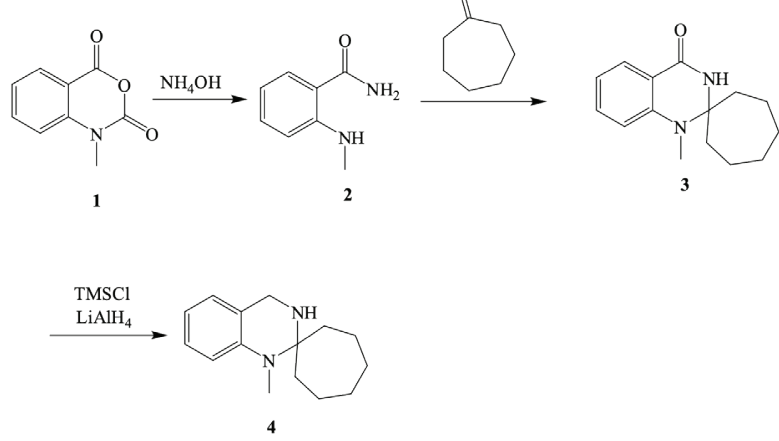

Scheme 1. Synthesis of compound 2-4.

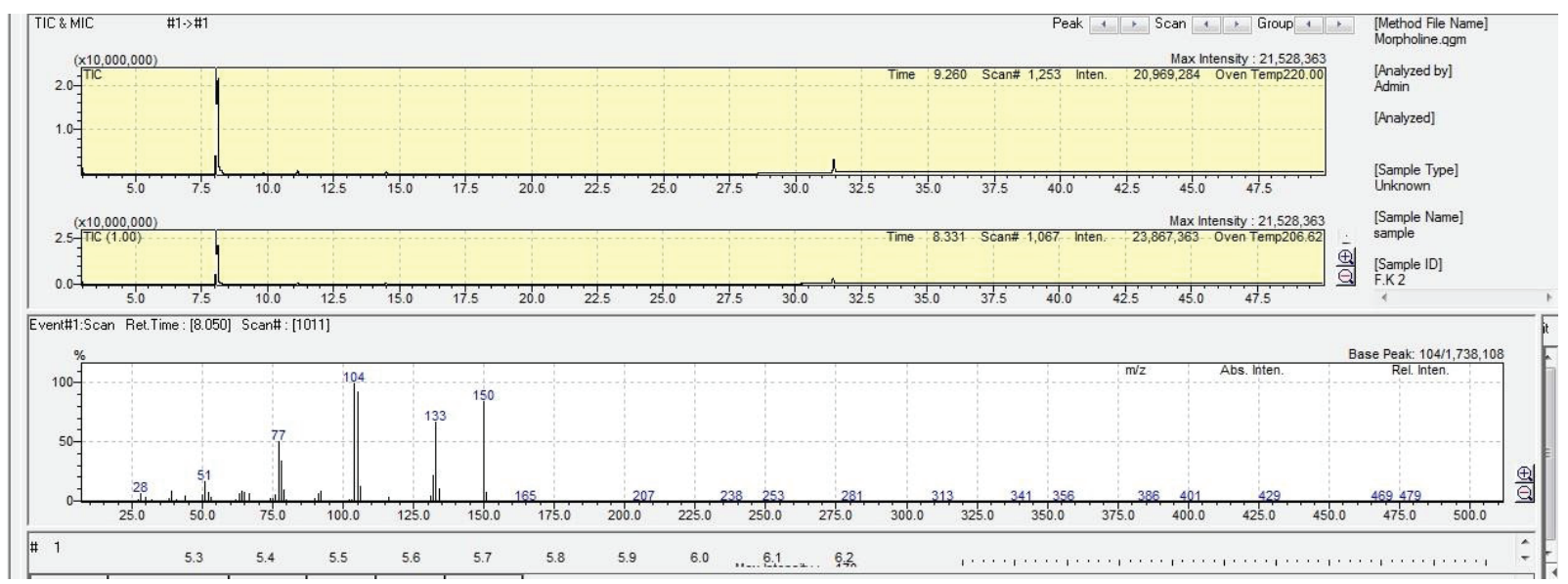

Figure 1. GC-MS spectrum of the compound 2 . 

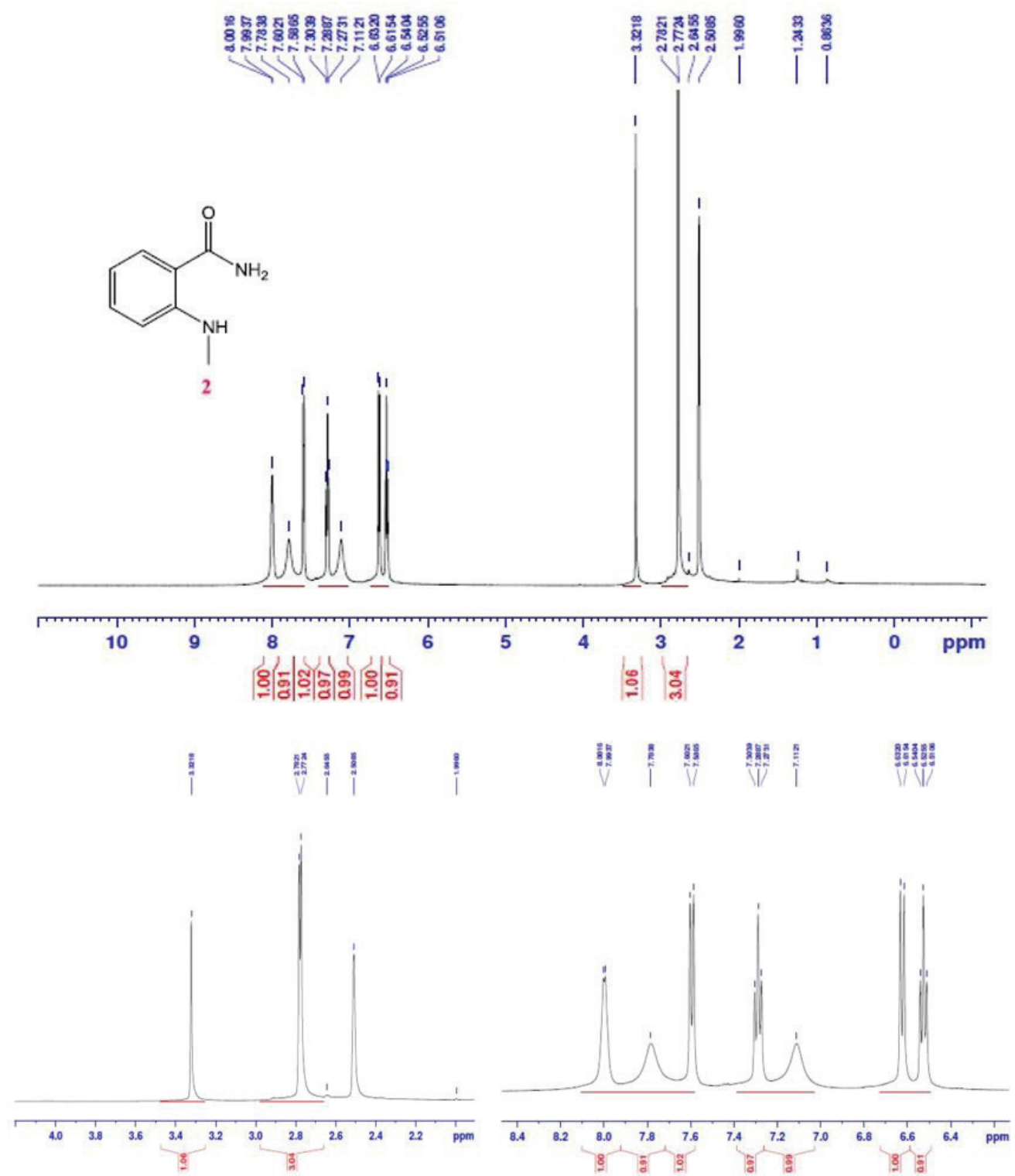

Figure 2. ${ }^{1} \mathrm{H}$ NMR spectrum for compound $\mathbf{2}$

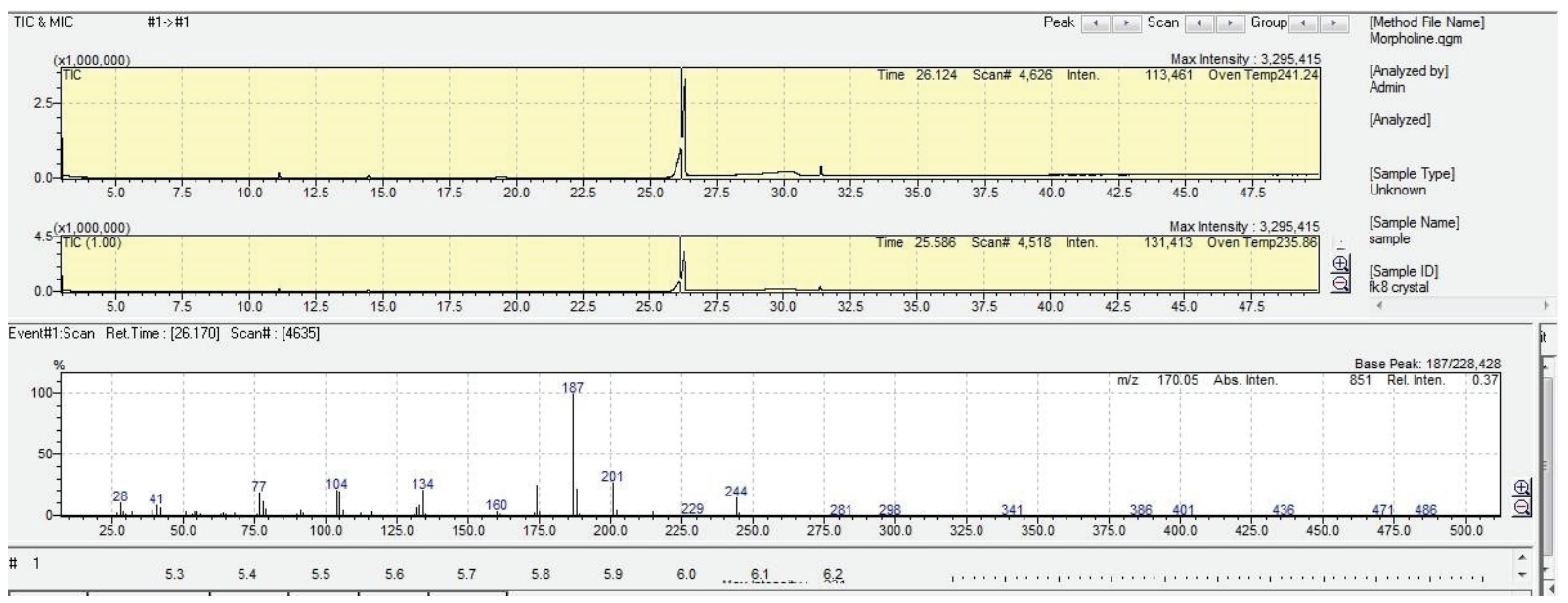

Figure 3. GC-MS spectrum for compound $\mathbf{3}$. 

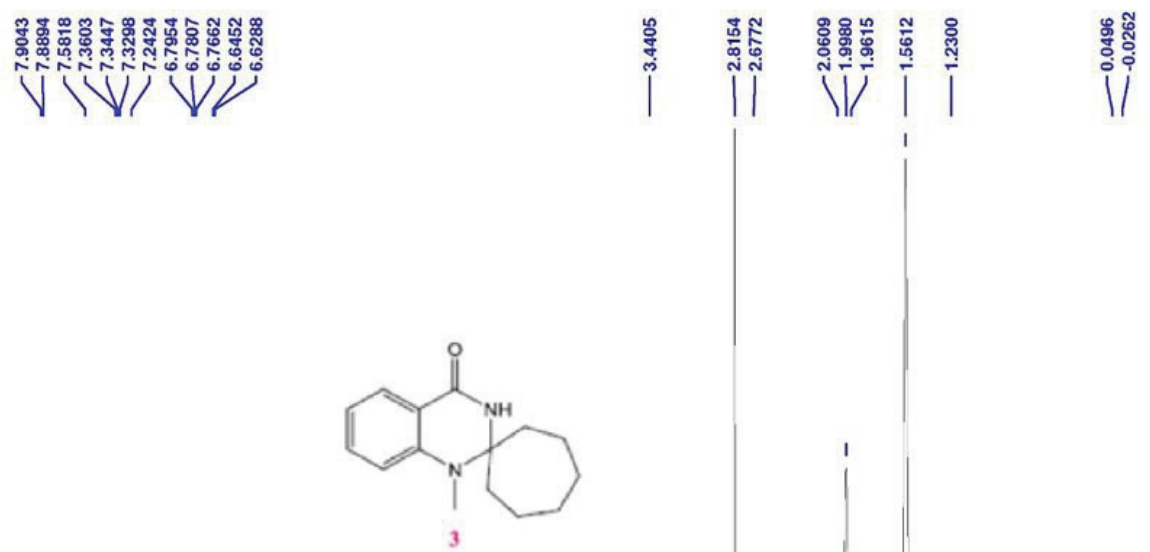

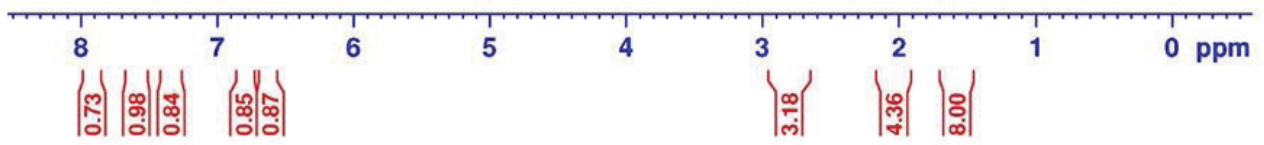

繁

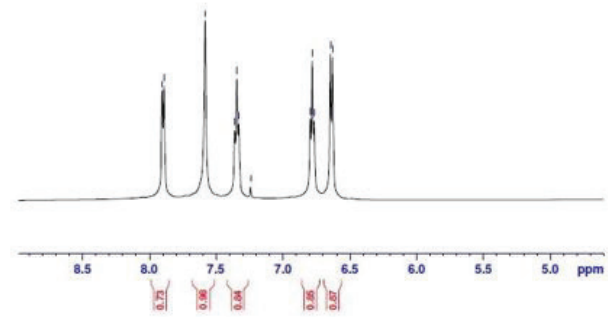

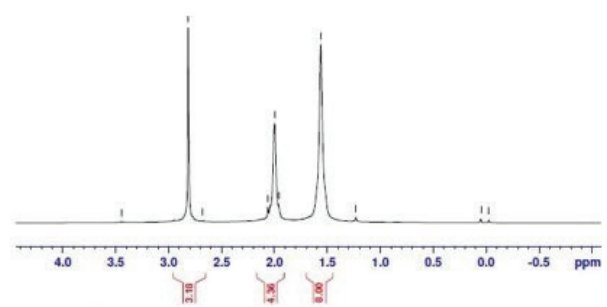

Figure 4. ${ }^{1 H}$ NMR spectrum for compound $\mathbf{3}$

77.08 (NCN), 112.62 (arom.), 116.72 (arom.), 117.59 (arom.), 128.13 (arom.), 134.01 (arom.), 148.14 (arom.), 164.51 (CO). (Figure 5).

\section{1'-methyl-3',4'-dihydro-1'H-spiro[cycloheptane-1,2'-} quinazoline] (4).

\%Yield: (97\%), color: yellow oily liquid, Rf: 0.2 (Hexane /EtOAc = 1:1), MS m/z = 230. (Figure 6).

${ }^{1} \mathrm{H}-\mathrm{NMR}\left(500 \mathrm{MHz}, \mathrm{CDCl}_{3}\right.$ ): $\delta=1.40-1.98$ (m, 12H, cycloheptyl), 2.75 (s, NH, brd), $2.90\left(\mathrm{~s}, 3 \mathrm{H}, \mathrm{CH}_{3}\right), 3.82\left(\mathrm{~s}, 2 \mathrm{H}, \mathrm{CH}_{2}\right)$, 6.6-6.9 (m, $2 \mathrm{H}, \mathrm{ArH}), 7.08(\mathrm{~d}, 1 \mathrm{H}, J=7.1 \mathrm{~Hz}, \mathrm{ArH}), 7.26\left(\mathrm{dd}, 1 \mathrm{H}, J_{1}=7.7 \mathrm{~Hz}, J_{2}\right.$
${ }^{13} \mathrm{C}-\mathrm{NMR}\left(125 \mathrm{~Hz}, \mathrm{CDCl}_{3}\right): \delta=23.11,24.26,28.71$ (cyclohept.), $30.24\left(\mathrm{CH}_{3}\right), 34.87$

(cyclohept.), $51.33\left(\mathrm{CH}_{2} \mathrm{~N}\right), 58.54$ (NCN), 109.68 (arom.), 116.14 (arom.), 124.49 (arom.), 128.56 (arom.), 129.30 (arom.), 149.59 (arom.) (Figure 8).

\section{RESULTS AND DISCUSSION}

Compound $\mathbf{2}$ was synthesized through the reaction of compound $\mathbf{1}$ with $\mathrm{NH}_{3}$ aqueous solution (32\%) at $30{ }^{\circ} \mathrm{C}$ causing ring opening with liberation of carbon dioxide gas, affording the title compound with a good yield as previously confirmed in literature (Zhao et al., 2014). . 


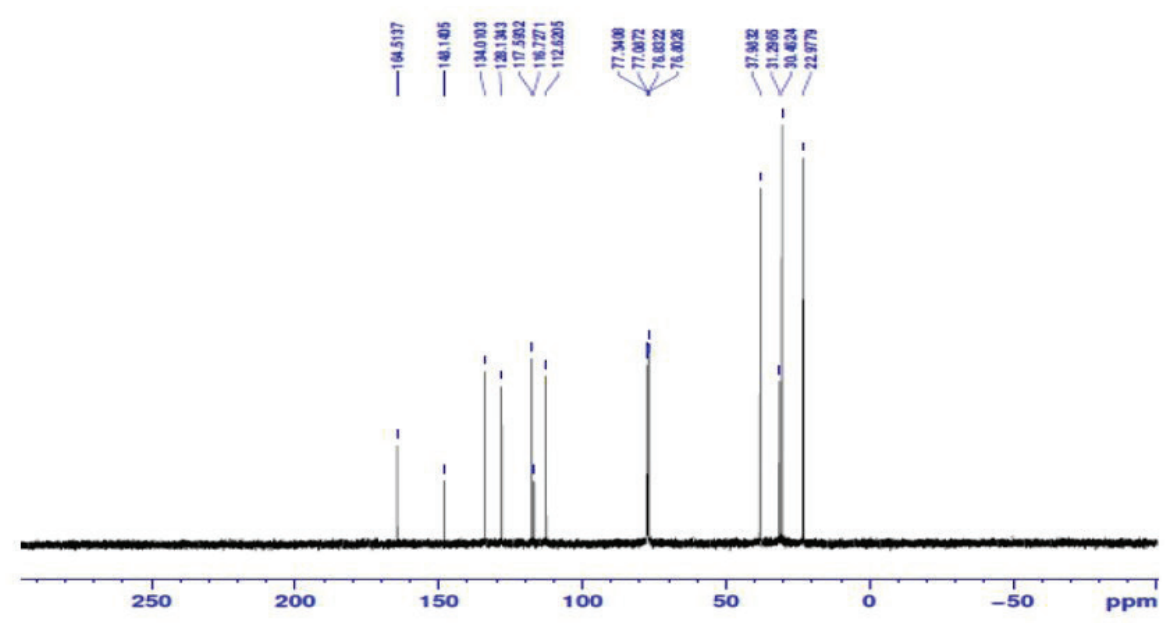

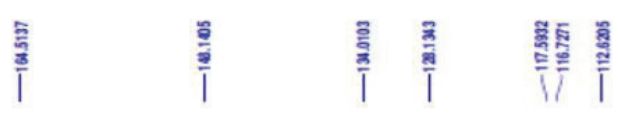

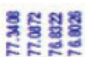

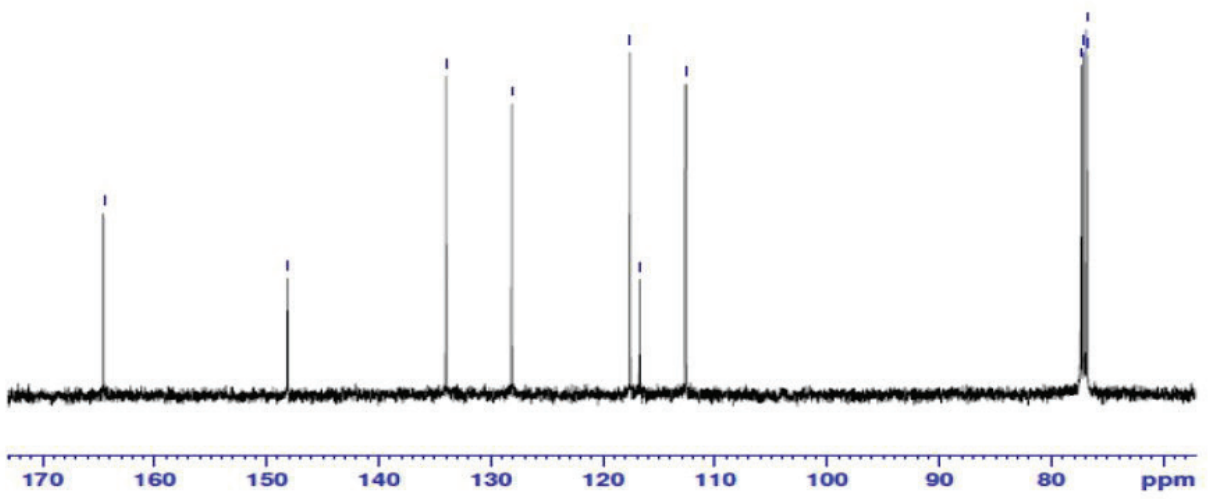

Figure 5. ${ }^{13} \mathrm{C}$ NMR spectrum for compound $\mathbf{3}$.

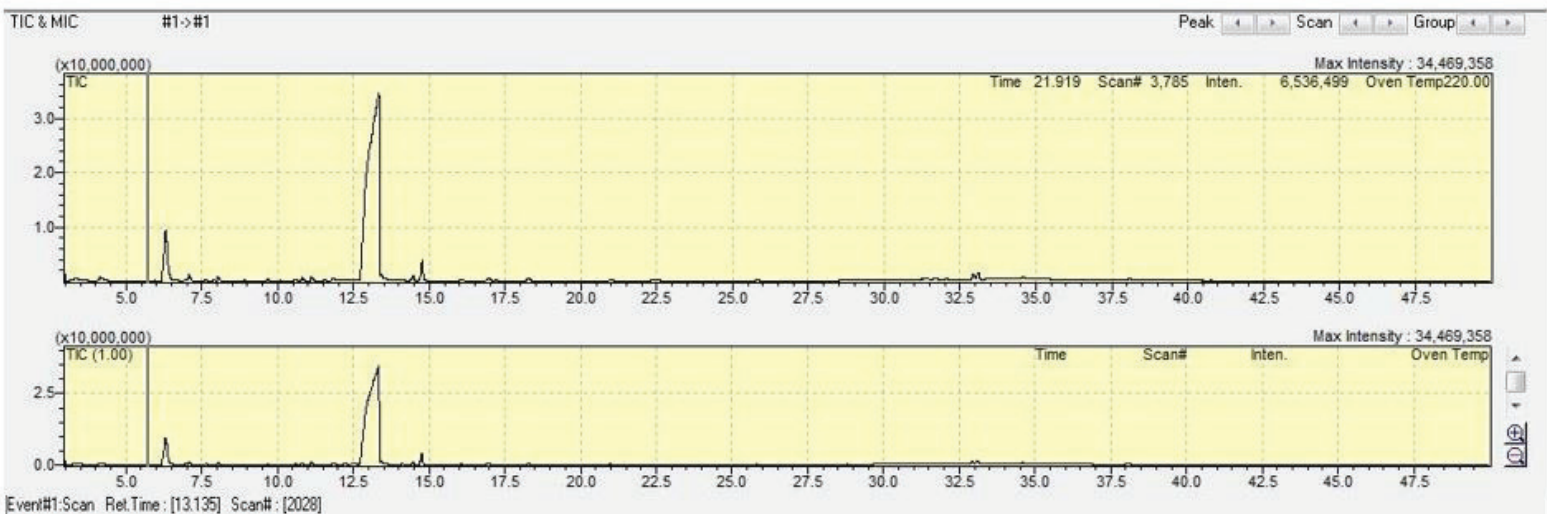

Event:H1:Scan Ret.Time: [13.135] Scan\#: [2028]

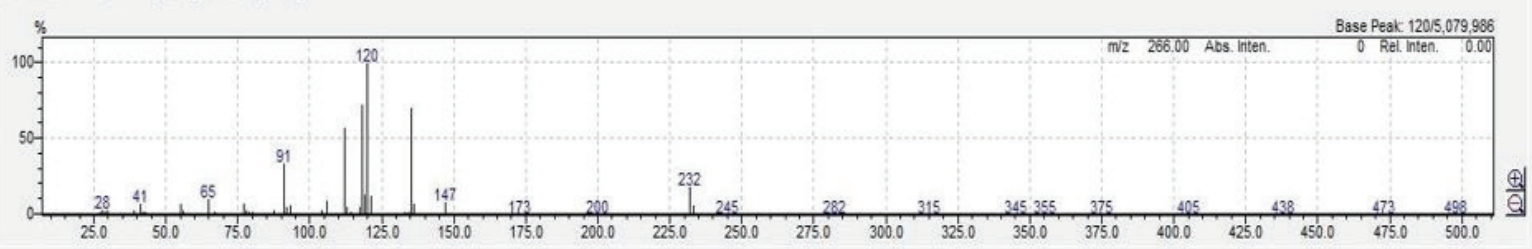

Figure 6. GC-MS spectrum for compound $\mathbf{4}$. 

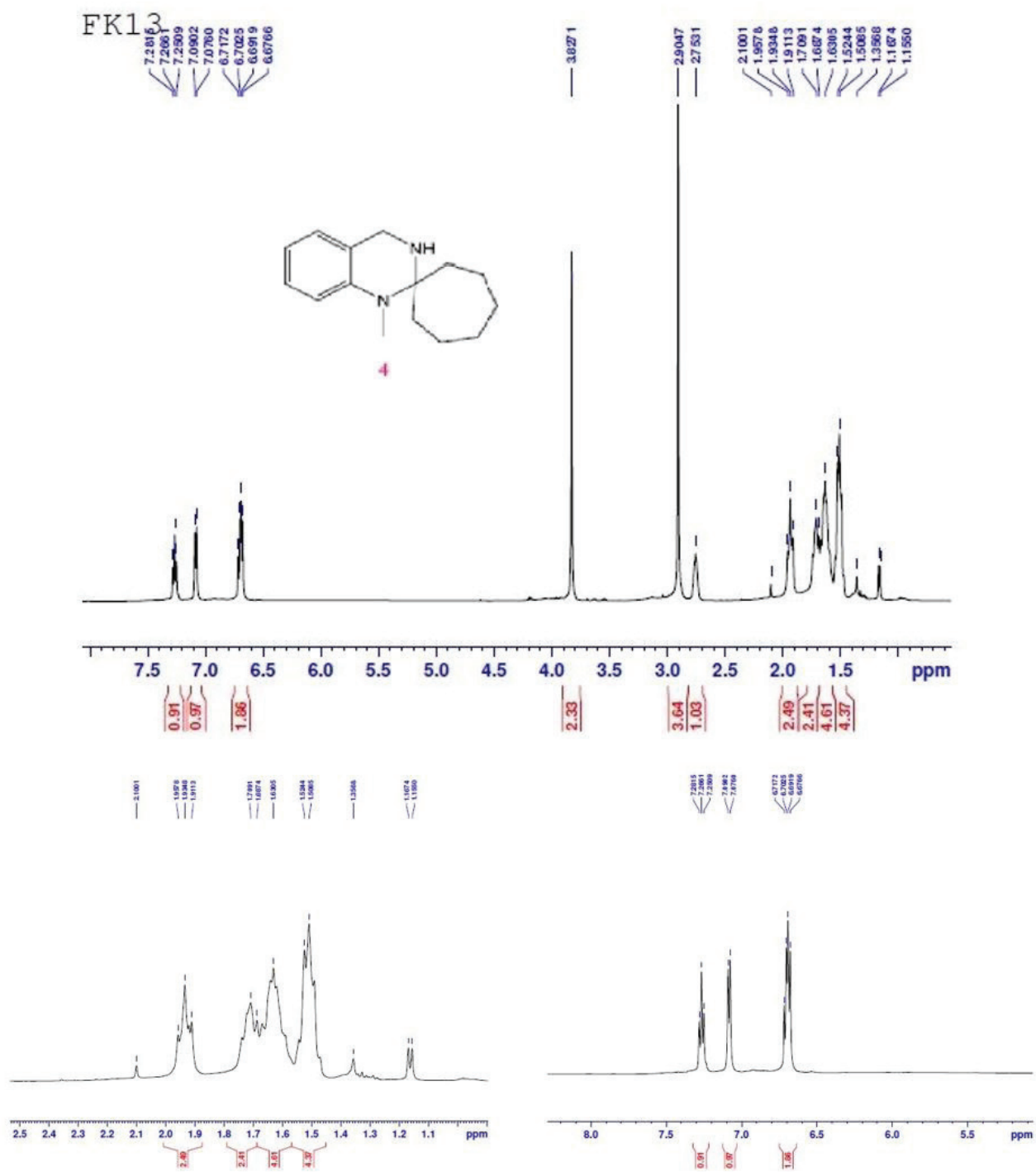

Figure 7. ${ }^{1} \mathrm{H}$ NMR spectrum for compound 4

To synthesize compound $\mathbf{3}$ toluene-4-sulfonic acid monohydrate was stirred with cycloheptanone and compound $\mathbf{2}$ in methanol under reflux for 3 hours. The reaction mixture was cooled to room temperature followed by stirring for $24 \mathrm{~h}$. Pure crystals were obtained with insufficient yield so we decided to optimize the reaction conditions. Reaction runs with different equivalents of cycloheptanone and different equivalents of toluene-4-sulfonic acid monohydrate. The yield was increased from $50 \%$ to $98 \%$ when equivalents of cycloheptanone increased from 2 to 3 and toluene 4-sulfonic acid monohydrate from 0.09 to 0.13 but was no effect on reaction time. Reaction conditions used for the optimization of compound $\mathbf{3}$ synthesis are summarized in Table 1.

To prepare compound $\mathbf{4}$ an expeditious and practical method for the reduction of amides to amines was performed (Ravinder, Rajeswar, Panasa, \& Rakeshwar, 2013). This method consists of activation of amides with TMSCl followed by reduction with $\mathrm{LiAlH}_{4}$. Various amides including hindered amides and secondary amides gave the corresponding amines in good to excel- lent yields. Plausible mechanism for the amide reduction via activation with TMSCl illustrated in the following Scheme 2.

According to this Scheme, compound $\mathbf{4}$ was synthesized as the following: TMSCl dissolved in sufficient quantity of THF then compound $\mathbf{3}$ was added with continuous stirring for 2 hours to activate carbonyl carbon in the amide moiety. Subsequently $\mathrm{LiAlH}_{4}$ was added to reduce activated carbonyl carbon and the progress of the reaction was monitored with TLC and GC-MS. When the reaction run with $2.5 \mathrm{eq}$ of TMSCl and 3.5 eq of $\mathrm{LiAlH}_{4}$ for 24 hours at room temperature TLC and GC-MS revealed no consumption of compound $\mathbf{3}$ and no product was formed, so we decide to optimize the reaction conditions. Reaction run again with $8.5 \mathrm{eq}$ of $\mathrm{LiAlH}_{4}$ this time, after 4 hour TLC and GC-MS revealed complete consumption of compound $\mathbf{3}$ with formation of mainly one product, product was extracted and $\%$ yield was calculated (good but insufficient). To maximize the reaction yield we decide to increase both eq of $\mathrm{LiAlH}_{4}$ and eq of TMSCl, after 1 hour TLC and GC-MS revealed complete consumption of compound $\mathbf{3}$ with formation of mainly 


\section{Table 1. Reaction conditions used for optimization of compound 3 synthesis.}

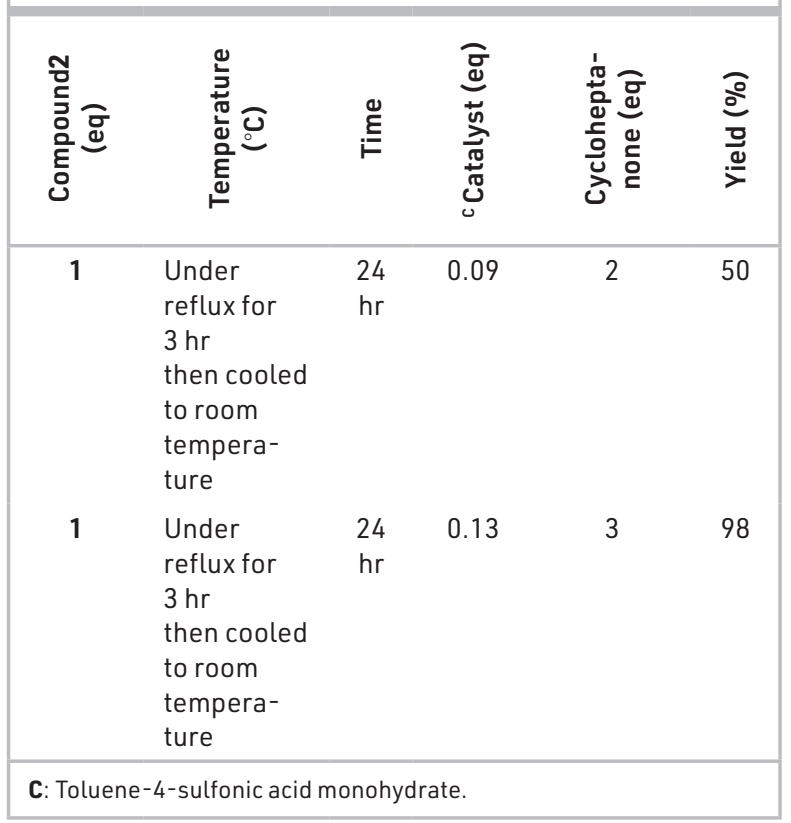
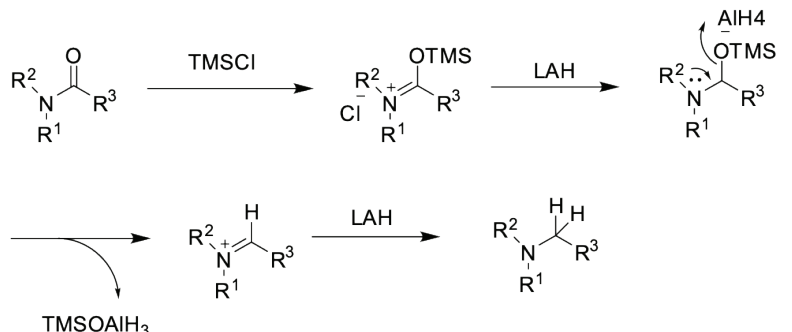

Scheme 2. Amide activation with TMSCl followed by reduction with $\mathrm{LAH}$.

one product, product was extracted and \% yield was calculated. Maximum yield obtained (97\%) with the shortening of reaction time. We concluded that the reaction needs different times to be done. Reaction optimization conditions are illustrated in Table 2.

\section{Table 2. Reaction conditions used for optimization of compound 4 synthesis.}

\begin{tabular}{|c|c|c|c|c|c|}
\hline 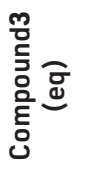 & 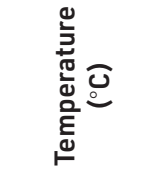 & $\stackrel{\stackrel{\mathscr{E}}{E}}{\models}$ & 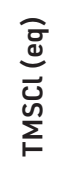 & 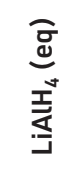 & $\begin{array}{l}\widehat{0} \\
\frac{0}{0} \\
\frac{0}{2}\end{array}$ \\
\hline 1 & $\begin{array}{l}\text { Room tem- } \\
\text { perature }\end{array}$ & $\begin{array}{l}24 \\
\mathrm{hr}\end{array}$ & 2.5 & 3.5 & 0 \\
\hline 1 & $\begin{array}{l}\text { Room tem- } \\
\text { perature }\end{array}$ & $\begin{array}{c}4 \\
\mathrm{hr}\end{array}$ & 2.5 & 8.5 & 60 \\
\hline 1 & $\begin{array}{l}\text { Room tem- } \\
\text { perature }\end{array}$ & $\begin{array}{c}1 \\
\mathrm{hr}\end{array}$ & 5 & 13.1 & 97 \\
\hline
\end{tabular}

\section{CONCLUSIONS}

Novel quinazoline derivatives: $\quad 1^{\prime}$-methyl- $1 H^{\prime}-$ spiro[cycloheptane-1,2'-quinazolin]-4'(3'H)-one (3) and 1'-methyl-3',4'-dihydro-1'H-spiro[cycloheptane-1,2'-quinazoline] (4) were synthesized. Furthermore, the reaction conditions were optimized for the synthesis of compounds $\mathbf{3}$ and $\mathbf{4}$ affording an excellent yield.

Peer-review: Externally peer-reviewed.

Author Contributions: Conception/Design of Study- Z.A., Q.A.; Data Acquisition- Z.A., Q.A., F.A., L.H.; Data Analysis/Interpretation- Z.A., Q.A., F.A., L.H.; Drafting Manuscript- Z.A., Q.A., F.A., L.H.; Critical Revision of Manuscript- Z.A., Q.A., F.A., L.H.; Final Approval and Accountability- Z.A., Q.A., F.A., L.H.

Conflict of Interest: The authors have no conflict of interest to declare.

Financial Disclosure: This work was supported Isra University, Faculty of Pharmacy.

\section{REFERENCES}

- $\quad$ Abualassal, Q., Abudayeh, Z., \& Husien- Al-Ali, S. H. (2019). Synthesis of a Spiro Quinazoline Compound as Potential Drug Useful in the Treatment of Alzheimer's Disease. Pharmakeftiki Journal, 2 (31), 60-68 Retrieved from https://www.hsmc.gr/wp-content/uploads/2015/12/ISSUE_2_2019.pdf

Ajani, O. O., Aderohunmu, D. V., Umeokoro, E. N., \& Olomieja, A. O. (2016). Quinazoline Pharmacophore in Therapeutic Medicine. Bangladesh Journal of Pharmacology, 11(3), 716-733. https://doi. org/ 10.3329/bjp.v11i3.25731.

- Apostolova, L. G. (2016). Alzheimer Disease. Continuum (Minneap Minn), 22(2), 419-434. https://doi.org/10.1212/ CON.0000000000000307.

Bekris, L. M., Yu, C. E., Bird, T. D., \& Tsuang, D. W. (2010). Genetics of Alzheimer Disease. Journal of Geriatric Psychiatry and Neurology, 23(4), 213-227. https://doi.org/ 10.1177/0891988710383571.

Benny, A., \& Thomas, J. (2019). Essential Oils as Treatment Strategy for Alzheimer's Disease: Current and Future Perspectives. Planta Medica, 85(03), 239-248. https://doi.org/10.1055/a-0758-0188.

- Darras, F. H., Wehle, S., Huang, G., Sotriffer, C. A., \& Decker, M. (2014). Amine Substitution of Quinazolinones Leads to Selective Nanomolar AChE Inhibitors with 'Inverted'Binding Mode. Bioorganic and Medicinal Chemistry, 22(17), 4867-4881. https://doi. org/10.1016/j.bmc.2014.06.045.

- $\quad$ Douchamps, V., \& Mathis, C. (2017). A Second Wind for the Cholinergic System in Alzheimer's Therapy. Behavioural Pharmacology, 28 (2 and 3-Spec Issue), 112-123. https://doi.org/ 10.1097/ FBP.0000000000000300.

- Hampel, H., Mesulam, M. M., Cuello, A. C., Farlow, M. R., Giacobini, E., Grossberg, G. T., Khachaturian, A. S., Vergallo, A., Cavedo, E., Snyder, P. J., \& Khachaturian, Z. S. (2018). The Cholinergic System in the Pathophysiology and Treatment of Alzheimer's Disease. Brain, 141(7), 1917-1933. https://doi.org/ 10.1093/brain/awy132.

Hung, S. Y., \& Fu, W. M. (2017). Drug Candidates in Clinical Trials for Alzheimer's Disease. Journal of Biomedical Science, 24(1), 47. https://doi.org/ 10.1186/s12929-017-0355-7.

- $\quad$ Kamel M. M., Zaghary W. A., Al-Wabli R., \& Anwar M. M. (2016). Synthetic Approaches and Potential Bioactivity of Different Functionalized Quinazoline and Quinazolinone Scaffolds. Egyptian Pharmaceutical Journal, 15(3), 98-131. https://doi.org/ 10.4103/1687-4315.197580. 
- $\quad$ Kivimäki, M., \& Singh-Manoux A. (2018). Prevention of Dementia by Targeting Risk Factors. The Lancet, 391(10130), 1574-1575. https://doi.org/ 10.1016/S0140-6736(18)30578-6.

- Lazo-Porras, M., Ortiz-Soriano, V., Moscoso-Porras, M., RunzerColmenares, FM., Málaga, G., \& Jaime Miranda, J. (2017). Cognitive Impairment and Hypertension in Older Adults Living in Extreme Poverty: A Cross-Sectional Study in Peru. BMC Geriatric, 17(1), 250. https://doi.org/10.1186/s12877-017-0628-8.

- Li, Z., Wang, B., Hou, J. Q., Huang, S. L., Ou, T. M., Tan, J. H., An, L. K., Li, D., Gu, L. Q., \& Huang, Z. S. (2013). 2-(2-indolyl-)-4(3H)-quinazolines Derivates as New Inhibitors of AChE: Design, Synthesis, Biological Evaluation and Molecular Modelling. Journal of Enzyme Inhibition and Medicinal Chemistry, 28(3), 583-592. https://doi. org/ 10.3109/14756366.2012.663363.

- Mendiola-Precoma, J., Berumen L. C., Padilla, K., \& Garcia-Alcocer, G. (2016). Therapies for Prevention and Treatment of Alzheimer's Disease. BioMed Research International, 2016(3), 1-17. https://doi. org/10.1155/2016/2589276.

- Mohamed, T., Manna, M. K., \& Rao, P. P. N. (2017). Application of Quinazoline and Pyrido[3,2- $d$ ] Pyrimidine Templates to Design Multi-Targeting Agents in Alzheimer's Disease. RSC Advances, 7(36), 22360-22368. https://doi.org/ 10.1039/c7ra02889j.

- Mohamed, T., \& Rao, P. P. N. (2017). 2,4-Disubstituted Quinazolines as Amyloid- $\beta$ Aggregation Inhibitors with Dual Cholinesterase Inhibition and Antioxidant Properties: Development and Structure-Activity Relationship (SAR) Studies. European Journal of Medicinal Chemistry, 126, 823-843. https://doi.org/ 10.1016/j.ejmech.2016.12.005.

- $\quad$ Naderali, E. K., Ratcliffe, S. H., \& Dale, M. C. (2009). Obesity and Alzheimer's Disease: A Link Between Body Weight and Cognitive Function in Old Age American Journal of Alzheimer's Disease and Other Dementias, 24(6), 445-449. https://doi.org/ $10.1177 / 1533317509348208$.
Olivares, D., Deshpande V. K., Shi, Y., Lahiri, D. K., Greig, N. H., Rogers, J. T., \& Huang, X. (2012). N-methyl D-aspartate (NMDA) Receptor Antagonists and Memantine Treatment for Alzheimer's Disease, Vascular Dementia and Parkinson's Disease. Current Alzheimer Research, 9(6), 746-758. https://doi. org/10.2174/156720512801322564.

Panpalli Ates, M., Karaman, Y., Guntekin, S., \& Ergun, M.A. (2016). Analysis of Genetics and Risk Factors of Alzheimer's disease. Neuroscience, 14(325), 124-131. https://doi.org/ 10.1016/j.Neuroscience.2016.03.051.

- Park, B., Nam, J. H., Kim, J. H., Kim H. J., Onnis, V., Balboni, G., Lee K. T., Park, J. H., Catto, M., Carotti, A., \& Lee, J. Y. (2017) . 3,4-Dihydroquinazoline Derivatives Inhibit the Activities of Cholinesterase Enzymes. Bioorganic \& Medicinal Chemistry Letters, 27(5), 11791185. https://doi.org/ 10.1016/j.bmcl.2017.01.068.

- $\quad$ Ravinder, B., Rajeswar, R. S., Panasa R. A., \& Rakeshwar, B. (2013). Amide Activation by TMSCl: Reduction of Amides to Amines by LiAlH4 under Mild Conditions. Tetrahedron Letters, 54(36), 49084913. https://doi.org/10.1016/j.tetlet.2013.06.144.

- $\quad$ Szeto, J.Y.Y., Simon J.G., \& Lewis, S.J.G (2016). Current Treatment Options for Alzheimer's Disease and Parkinson's Disease Dementia. Current Neuropharmacology, 14(4), 326-338. https://doi.org/ 10.2174/1570159X14666151208112754

- $\quad$ Tariq, S., \& Barber, P. A. (2018). Dementia Risk and Prevention by Targeting Modifiable Vascular Risk Factors. Journal of Neurochemistry, 144(5), 565-581. https://doi.org/ 10.1111/jnc.14132.

- Zhao, D., Wang, T., \& Li, J. X. (2014). Metal-Free Oxidative Synthesis of Quinazolinones via Dual Amination of sp3 C-H Bonds. Chemical Communications, 50(49), 6471-6474. https://doi.org/10.1039/ C4CC02648A. 